\title{
Synthesis of Poly(cyclodiborazane)s by Hydroboration Polymerization Using Mesitylborane
}

\author{
Noriyoshi Matsumi, Kensuke NaKa, and Yoshiki Chujo ${ }^{\dagger}$ \\ Department of Polymer Chemistry, Graduate School of Engineering, \\ Kyoto University, Yoshida, Sakyo-ku, Kyoto 606-8501, Japan
}

(Received April 9, 1998)

\begin{abstract}
Novel methodology for the preparation of poly(cyclodiborazane) was explored by hydroboration polymerization of dicyano compounds with mesitylborane. This method provides a useful way to prepare high molecular weight poly(cyclodiborazane) under mild reaction conditions. Hydroboration polymerization between adiponitrile and mesitylborane was examined under various conditions. As a result, the best condition was optimized to be adding a tetrahydrofuran solution of mesitylborane to adiponitrile at $0^{\circ} \mathrm{C}$ and gradually warming up the reaction mixture to room temperature. The gel permeation chromatographic analysis showed that the number average molecular weight of the resulting polymer was 12000 . Hydroboration polymerization by using various dicyano compounds was also examined. It was found that both aliphatic and aromatic dicyano compounds gave the corresponding polymers having relatively high molecular weights irrespective of the kinds of monomers employed.
\end{abstract}

KEY WORDS Inorganic Polymer / Organoboron Polymer / Hydroboration Polymerization / Poly(cyclodiborazane) /

Recently, we have reported novel methodologies for the synthesis of boron-containing polymers by "Boration Polymerization." ${ }^{1,2}$ In most cases, the obtained polymers were relatively unstable to air or moisture. However, the novel type of organoboron main-chain polymers served as a key intermediate for poly(alcohol)s, poly(ketone)s, and so on. On the other hand, hydroboration polymerization of dicyano compounds gave air-stable organoboron polymers bearing cyclodiborazane units in their backbone $^{3}$ (Scheme 1). This polymerization proceeds via dimerization of iminoborane, which is generated by monohydroboration of cyano group. Allylboration polymerization by using triallylborane is also an effective method to produce poly(cyclodiborazane)s. ${ }^{4}$ The obtained polymers are expected not only as a novel type of air-stable organoboron materials but also as a polymeric precursor for boron-containing ceramics.

Furthermore, these polymerization systems enable the polymerization of various cyano group-containing compounds that are not polymerized by conventional methods. ${ }^{5}$ The cyano groups can be used for polymerization, but the electron-withdrawing property would be still remained even after the reaction due to the electron accepting organoboron units.

In order to explore further methodology for the synthesis of poly(cyclodiborazane)s, hydroboration polymerization of dicyano compounds by using mesitylborane (1) was examined (Scheme 2). This method provides a convenient approach for the preparation of high molecular weight poly(cyclodiborazane)s from both aliphatic and aromatic dicyano compounds.

\section{EXPERIMENTAL}

\section{Materials and Instruments}

Tetrahydrofuran (THF) was dried over sodium and distilled before use. Mesitylborane was prepared by the

\footnotetext{
$\dagger$ To whom correspondence should be addressed.
}

modified procedure of reported method. ${ }^{6}$ Dicyano compounds were purified by distillation.

${ }^{1} \mathrm{H},{ }^{13} \mathrm{C},{ }^{11} \mathrm{~B}$ NMR spectra were recorded in $\mathrm{CDCl}_{3}$ on a JEOL EX-270 instrument. Gel permeation chromatographic (GPC) analysis was carried out on a TOSOH G3000HXI by using THF as an eluent after calibration with standard polystyrene samples. IR spectrum was obtained on a Perkin Elmer 1600 spectrometer. Thermogravimetric analysis (TGA) was made on a Shimadzu DT-30 instrument $\left(10^{\circ} \mathrm{C} \mathrm{min}^{-1}\right)$.

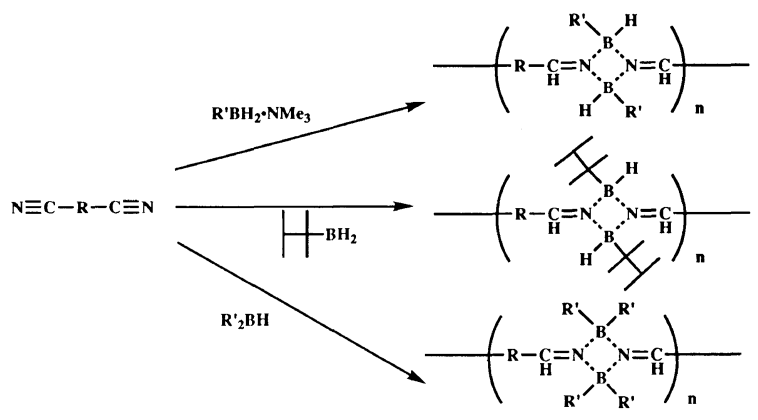

Scheme 1.

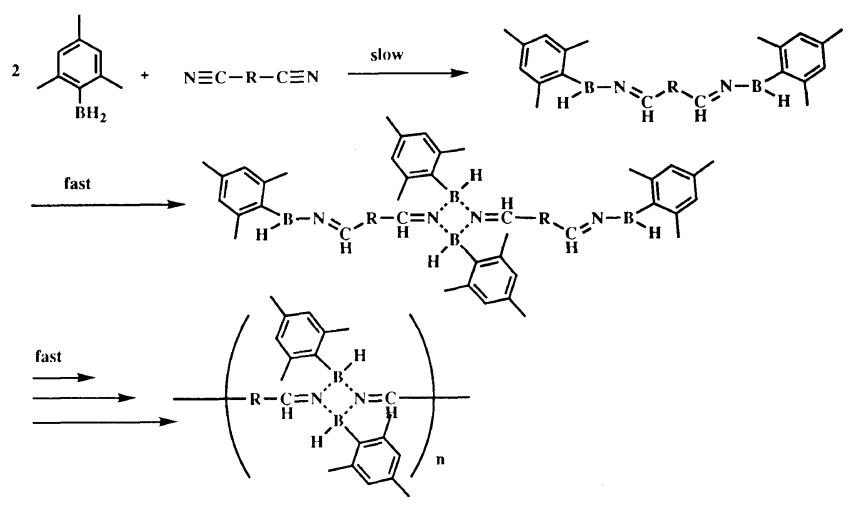

Scheme 2. 
Polyaddition between Mesitylborane (1) and Adiponitrile (2b)

The dependence of the molecular weight of the obtained polymer on the feed ratio of monomers was examined as follows. To a $1.0 \mathrm{M}$ THF solution of 1 , a half molar amount of $\mathbf{2 b}$ was added slowly at $0^{\circ} \mathrm{C}$. After stirring for $2 \mathrm{~h}$, the reaction mixture was warmed up to room temperature and stirred for another $2 \mathrm{~h}$. The reaction mixture was directly subjected to GPC analysis. Amounts of $\mathbf{1}$ and $\mathbf{2 b}$ used are summarized in Table II.

As a typical example of polymerization, $2 \mathbf{b}(42.5 \mathrm{mg}$, $0.393 \mathrm{mmol}$ ) was added to $1.0 \mathrm{M}$ THF solution of 1 $(120.0 \mathrm{mg}, 0.909 \mathrm{mmol})$ at $0^{\circ} \mathrm{C}$ under nitrogen and the reaction mixture was stirred for $2 \mathrm{~h}$. Then the mixture was warmed up to room temperature and stirred for additional $2 \mathrm{~h}$. The obtained colorless gum was reprecipitated into $\mathrm{H}_{2} \mathrm{O} / \mathrm{MeOH}=1 / 1(\mathrm{v} / \mathrm{v})$ and dried in vacuo. The polymer (3b) was obtained as a white powder $(137.5 \mathrm{mg}$, yield $94 \%$ ) and was soluble in common organic solvents such as dichloromethane, THF, and benzene. ${ }^{1} \mathrm{H}$ NMR $(\delta, \mathrm{ppm}) 1.12\left(\mathrm{CH}_{2}-\mathrm{C}-\mathrm{CH}=\mathrm{N}, 4 \mathrm{H}\right)$, $1.89\left(\mathrm{CH}_{2}-\mathrm{CH}=\mathrm{N}, 4 \mathrm{H}\right), 2.30\left(\mathrm{Ar}-\mathrm{CH}_{3}, 18 \mathrm{H}\right), 6.87$ $(\mathrm{Ar}-H, 4 \mathrm{H}), 7.30(\mathrm{CH}=\mathrm{N}, 2 \mathrm{H}) \cdot{ }^{13} \mathrm{C} \mathrm{NMR}(\delta, \mathrm{ppm}) 20.9$ $(C-\mathrm{C}-\mathrm{CH}=\mathrm{N}), 23.7,24.8(C-\mathrm{CH}=\mathrm{N}), 33.7(\mathrm{Ar}-C)$, $128.6(\mathrm{~B}-\mathrm{C}), 136.6(\mathrm{~B}-\mathrm{C}-\mathrm{C}-\mathrm{C}), 143.3(\mathrm{~B}-\mathrm{C}-\mathrm{C}-\mathrm{C}-\mathrm{C})$, $165.5(C=\mathrm{N}) .{ }^{11} \mathrm{~B} \operatorname{NMR}(\delta, \mathrm{ppm}) 1.15 . \operatorname{IR}\left(v, \mathrm{~cm}^{-1}\right)$ $1682(\mathrm{C}=\mathrm{N}), 2415(\mathrm{~B}-\mathrm{H})$.

\section{Polymerization between Various Aliphatic Dicyano Com- pounds and $\mathbf{1}$}

The following organoboron polymers were prepared by the procedure similary to that described for $\mathbf{3 b}$. 3a; yield $84 \%$. ${ }^{1} \mathrm{H}$ NMR $(\delta, \mathrm{ppm}) 1.19\left(\mathrm{CH}_{2}-\mathrm{C}-\mathrm{CH}=\mathrm{N}\right.$, $2 \mathrm{H}), 1.89\left(\mathrm{CH}_{2}-\mathrm{CH}=\mathrm{N}, 4 \mathrm{H}\right), 2.32\left(\mathrm{Ar}-\mathrm{CH}_{3}, 18 \mathrm{H}\right), 6.87$ $(\mathrm{Ar}-\mathrm{H}, 4 \mathrm{H}), 7.31(\mathrm{CH}=\mathrm{N}, 2 \mathrm{H}) .3 \mathrm{c}$; yield $95 \% .{ }^{1} \mathrm{H}$ NMR $\left(\delta\right.$, ppm) $0.86-1.62\left(\mathrm{~N}=\mathrm{C}-\mathrm{C}-\mathrm{CH}_{2}-\mathrm{CH}_{2}, 6 \mathrm{H}\right), 1.82$ $\left(\mathrm{CH}_{2}-\mathrm{CH}=\mathrm{N}, 4 \mathrm{H}\right), 2.29\left(\mathrm{Ar}-\mathrm{CH}_{3}, 18 \mathrm{H}\right), 6.79(\mathrm{Ar}-\mathrm{H}$, $4 \mathrm{H}), 7.30(\mathrm{~N}=\mathrm{CH}, 2 \mathrm{H}) .3 \mathrm{~d}$; yield $95 \% .{ }^{1} \mathrm{H} \mathrm{NMR}(\delta$, ppm) $0.83-1.62\left(-\mathrm{N}=\mathrm{C}-\mathrm{C}-\mathrm{CH}_{2}-\mathrm{CH}_{2}, 12 \mathrm{H}\right), \quad 1.80$ $\left(\mathrm{CH}_{2}-\mathrm{CH}=\mathrm{N}, 4 \mathrm{H}\right), 2.31\left(\mathrm{Ar}-\mathrm{CH}_{3}, 18 \mathrm{H}\right), 6.74(\mathrm{Ar}-\mathrm{H}$, $4 \mathrm{H}), 7.30(\mathrm{~N}=\mathrm{CH}, 2 \mathrm{H}) .3 \mathrm{e}$; yield $96 \% .{ }^{1} \mathrm{H} \mathrm{NMR}(\delta$, ppm) $0.90-1.57\left(\mathrm{~N}=\mathrm{C}-\mathrm{C}-\mathrm{CH}_{2}-\mathrm{CH}_{2}-\mathrm{CH}_{2}, 12 \mathrm{H}\right), 1.89$ $\left(\mathrm{CH}_{2}-\mathrm{CH}=\mathrm{N}, 4 \mathrm{H}\right), 2.34\left(\mathrm{Ar}-\mathrm{CH}_{3}, 18 \mathrm{H}\right), 6.74(\mathrm{Ar}-\mathrm{H}$, $4 \mathrm{H}), 7.36(\mathrm{~N}=\mathrm{CH}, 2 \mathrm{H})$.

\section{Polyaddition between Mesitylborane (1) and Terephthalo- nitrile (4a)}

To a THF ( $3 \mathrm{ml})$ solution of $\mathbf{4 a}(44.5 \mathrm{mg}, 0.347 \mathrm{mmol})$, $1.0 \mathrm{M}$ THF solution of $1(92.8 \mathrm{mg}, 0.700 \mathrm{mmol})$ was added at room temperature. After stirring for $12 \mathrm{~h}$, the obtained colorless gum was reprecipitated into $\mathrm{H}_{2} \mathrm{O}$ / $\mathrm{MeOH}=1 / 1(\mathrm{v} / \mathrm{v})$ and dried in vacuo. The polymer (5a) was obtained as a white powder $(119.7 \mathrm{mg}$, yield $88 \%)$ and was soluble in common organic solvents such as dichloromethane, THF, and benzene. ${ }^{1} \mathrm{H}$ NMR $(\delta, \mathrm{ppm})$ $2.19\left(\mathrm{Ar}-\mathrm{CH}_{3}, 18 \mathrm{H}\right), 6.76(\mathrm{~B}-\mathrm{C}-\mathrm{C}-\mathrm{CH}, 4 \mathrm{H}), 7.34$ $(\mathrm{N}=\mathrm{C}-\mathrm{C}-\mathrm{CH}, 4 \mathrm{H}), 8.03(\mathrm{CH}=\mathrm{N}, 2 \mathrm{H})$.

\section{Polymerization between Mesitylborane (1) and Various Aromatic Dicyano Compounds}

The following organoboron polymers were prepared by the procedure similarly to that described for $\mathbf{5 a}$. 5b; yield $94 \%$. ${ }^{1} \mathrm{H} \operatorname{NMR}(\delta, \mathrm{ppm}) 1.86\left(\mathrm{O}-\mathrm{C}-\mathrm{CH}_{2}, 4 \mathrm{H}\right)$,
$2.27\left(\mathrm{Ar}-\mathrm{CH}_{3}, 18 \mathrm{H}\right), 3.97\left(\mathrm{O}-\mathrm{CH}_{2}, 4 \mathrm{H}\right), 6.72(\mathrm{~B}-\mathrm{C}-\mathrm{C}-$ $\mathrm{CH}, 4 \mathrm{H}), 7.43(\mathrm{~N}=\mathrm{C}-\mathrm{C}-\mathrm{CH}, 8 \mathrm{H}), 8.03(\mathrm{CH}=\mathrm{N}, 2 \mathrm{H})$. 5c; yield 97\%. ${ }^{1} \mathrm{H}$ NMR $(\delta, \mathrm{ppm}) 1.47\left(\mathrm{O}-\mathrm{C}-\mathrm{C}-\mathrm{CH}_{2}\right.$, $4 \mathrm{H}), 1.85\left(\mathrm{O}-\mathrm{C}-\mathrm{CH}_{2}, 4 \mathrm{H}\right), 2.27\left(\mathrm{Ar}-\mathrm{CH}_{3}, 18 \mathrm{H}\right), 3.92$ $\left(\mathrm{O}-\mathrm{CH}_{2}, 4 \mathrm{H}\right), 6.75(\mathrm{~B}-\mathrm{C}-\mathrm{C}-\mathrm{CH}, 4 \mathrm{H}), 7.43(\mathrm{~N}=\mathrm{C}-\mathrm{C}-$ $\mathrm{CH}, 8 \mathrm{H}), 8.02(\mathrm{CH}=\mathrm{N}, 2 \mathrm{H}) .5 \mathrm{~d}$; yield $92 \% .{ }^{1} \mathrm{H}$ NMR $(\delta, \mathrm{ppm}) 1.40\left(\mathrm{O}-\mathrm{C}-\mathrm{C}-\mathrm{CH}_{2}-\mathrm{CH}_{2}, 8 \mathrm{H}\right), 1.87\left(\mathrm{O}-\mathrm{C}-\mathrm{CH}_{2}\right.$, $4 \mathrm{H}), 2.29\left(\mathrm{Ar}-\mathrm{CH}_{3}, 18 \mathrm{H}\right), 3.93\left(\mathrm{O}-\mathrm{CH}_{2}, 4 \mathrm{H}\right), 6.77$ $(\mathrm{B}-\mathrm{C}-\mathrm{C}-\mathrm{CH}, \quad 4 \mathrm{H}), \quad 7.48 \quad(\mathrm{~N}=\mathrm{C}-\mathrm{C}-\mathrm{CH}, \quad 8 \mathrm{H}), \quad 8.04$ $(\mathrm{CH}=\mathrm{N}, 2 \mathrm{H})$.

\section{Air Stability of Organoboron Polymer}

The stability of organoboron polymer toward air oxidation was examined by monitoring the change of the molecular weights by GPC curve during an oxidation experiment, in which a stream of air was bubbled into a THF solution of organoboron polymer. After $24 \mathrm{~h}$, the resulting polymer was characterized by GPC.

\section{Stability of Organoboron Polymer in the Presence of Moisture}

To a THF solution of polymer, water was added under nitrogen and the mixture was magnetically stirred for $24 \mathrm{~h}$. From the GPC measurement, no decrease of molecular weight was observed.

\section{RESULTS AND DISCUSSION}

In the previously reported method for the synthesis of poly(cyclodiborazane)s, hydroboration polymerization required relatively severe reaction conditions to remove amine or to generate dialkylhydroborane species. This led to relatively crosslinked structure (Scheme 3(a)) in the resulting polymer. When dibutylborane was employed, the polymers were obtained under mild reaction conditions. However, in these bulk systems, the polymerization of aromatic dicyano compounds resulted in relatively lower molecular weights of the obtained polymers due to high viscosity of the reaction mixtures. To overcome these problems, it is an attractive approach to examine hydroboration polymerization by using sterically hindered monoalkyl- or arylborane, which is stable at ambient temperature. However, hydroboration polymerization using thexylborane gave low molecular weight oligomers, probably due to further hydroboration of iminoborane.

Mesitylborane (1) ${ }^{7}$ is known as a useful alternative to thexylborane by the improved stability and reaction

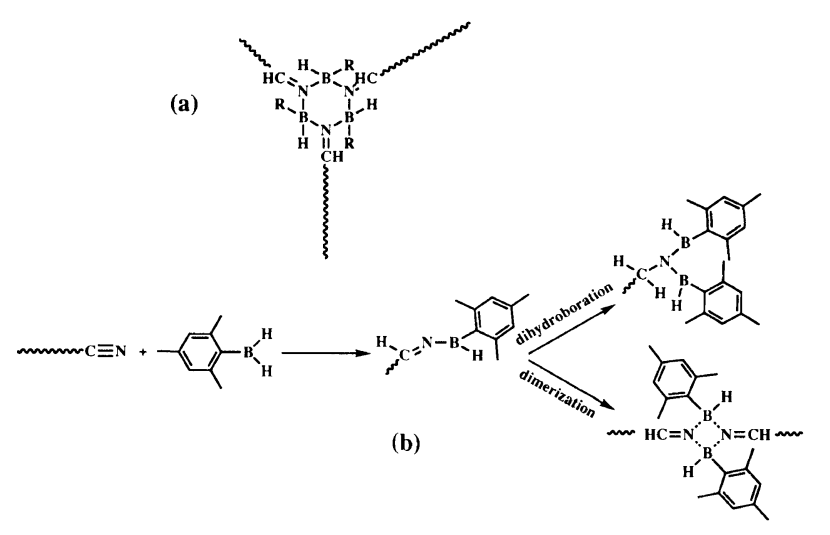

Scheme 3. 
Poly(cyclodiborazane) from Mesitylborane

Table I. Hydroboration polymerization of adiponitrile (2b) by using mesitylborane (1) under various reaction conditions ${ }^{\mathbf{a}}$

\begin{tabular}{cccccccc}
\hline Run & $\mathbf{1} / \mathbf{2 b}$ & Solvent & Temp $/{ }^{\circ} \mathbf{C}$ & $\boldsymbol{M}_{w}{ }^{\mathrm{b}}$ & $\boldsymbol{M}_{n}{ }^{\mathrm{b}}$ & $\boldsymbol{M}_{\boldsymbol{w}} / \boldsymbol{M}_{n}{ }^{\mathrm{b}}$ & Yield $/ \%^{\mathrm{c}}$ \\
\hline 1 & 2.01 & THF & r.t. & 20800 & 9000 & 2.3 & 90 \\
2 & 2.30 & THF & 0 -r.t. & 25000 & 12000 & 2.0 & 94 \\
3 & 2.38 & THF & $-78-$ r.t. & 4900 & 2100 & 2.3 & 89 \\
4 & 2.05 & Benzene & r.t & 27300 & 10500 & 2.6 & 97 \\
5 & 2.07 & $\mathrm{CH}_{2} \mathrm{Cl}_{2}$ & 0 -r.t. & 23600 & 9400 & 2.5 & 97 \\
\hline
\end{tabular}

${ }^{\mathrm{a}}$ Reactions were carried out by adding adiponitrile to a solution of mesitylborane. ${ }^{\mathrm{b}} \mathrm{GPC}(\mathrm{THF})$, polystyrene standards. ${ }^{\mathrm{c}}$ Isolated yields after reprecipitation into $\mathrm{MeOH} / \mathrm{H}_{2} \mathrm{O}=1 / 1(\mathrm{v} / \mathrm{v})$.

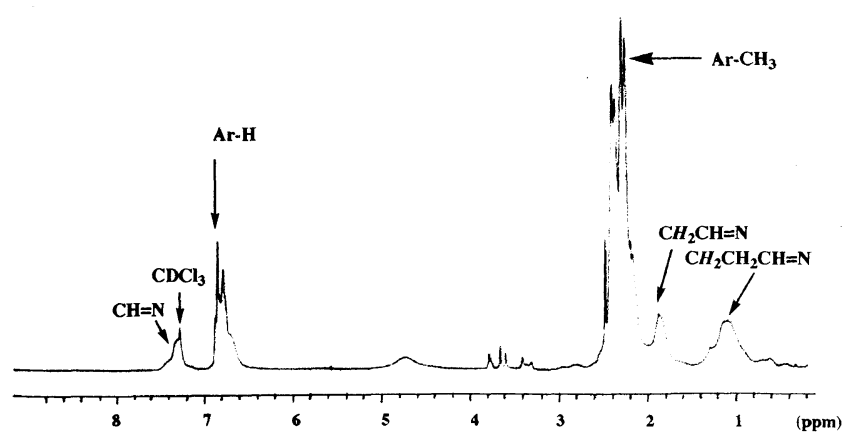

(a)

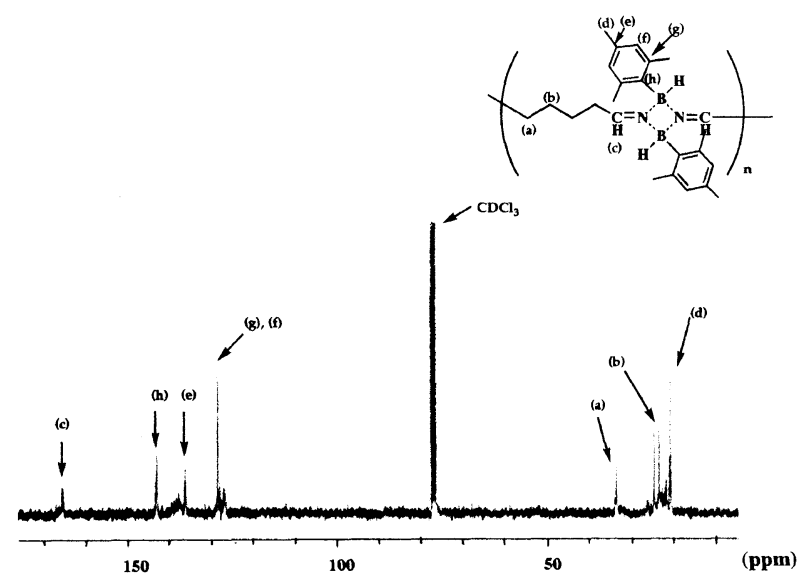

(b)

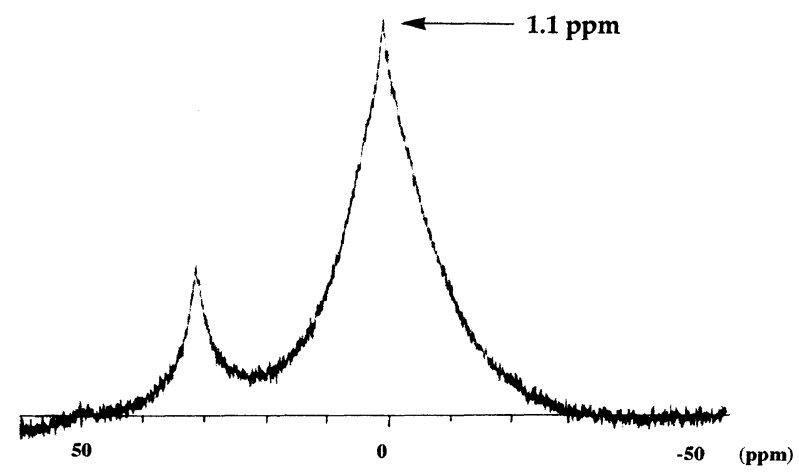

(c)

selectivity due to the severe steric hindrance around boron atom. Hydroboration polymerization between mesitylborane and dicyano compounds were thus examined as follows.

\section{Polymer Synthesis}

First of all, hydroboration polymerization between mesitylborane and adiponitrile (Scheme 2) was examined

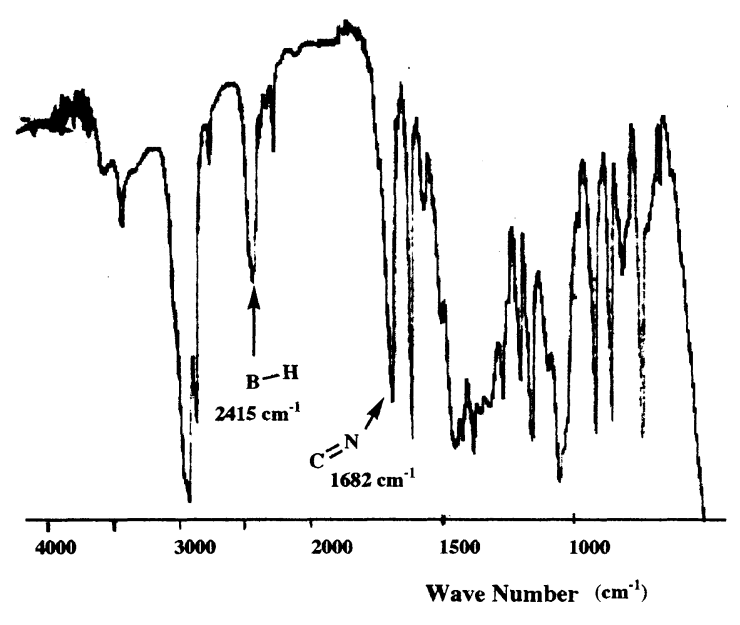

(d)

Figure 1. (a), ${ }^{1} \mathrm{H}$ NMR spectrum of $3 \mathbf{b} ;(\mathrm{b}),{ }^{13} \mathrm{C}$ NMR spectrum of $3 \mathbf{b}$; (c), ${ }^{11} \mathrm{~B}$ NMR spectrum of $\mathbf{3 b}$; (d), IR spectrum of $\mathbf{3 b}$.

under various reaction conditions (Table I). When the reaction was carried out at $0^{\circ} \mathrm{C}$-room temperature (r.t.), the corresponding polymer was readily obtained (run 2) as a colorless gum (a white solid after the reprecipitation). The GPC measurement showed that the numberaverage molecular weight of the polymer was 12000 (THF, polystyrene (PSt)). The molecular weight was slightly reduced $\left(M_{n} 9000\right.$, run 2$)$ in the case of reaction at r.t. (run 1). This is probably because of the lower selectivity between dimerization and further hydroboration at higher reaction temperature (Scheme 3(b)). In the polymerization using benzene or dichloromethane as a solvent, the polymer was also obtained in good efficiency.

\section{Polymer Structure}

The structure of the polymer (3b) was supported by ${ }^{1} \mathrm{H},{ }^{13} \mathrm{C},{ }^{11} \mathrm{~B}$ NMR, and IR spectra. These spectra are shown in Figure 1. In its ${ }^{1} \mathrm{H}$ NMR spectrum, methylene protons adjacent to $\mathrm{C}=\mathrm{N}$ were observed at $1.89 \mathrm{ppm}$, and the integral ratio between these protons and others was in good agreement with the calculated value for the expected structure. In the ${ }^{13} \mathrm{C}$ NMR spectrum of $\mathbf{3 b}$, a peak around $165.5 \mathrm{ppm}$ assignable to the imino carbon was observed. ${ }^{11} \mathbf{B}$ NMR spectrum of $\mathbf{3 b}$ shows its main peak around $1.15 \mathrm{ppm}$ corresponding to four-coordinated structure. In the IR spectrum, the peaks due to B-H stretching $\left(2415 \mathrm{~cm}^{-1}\right)$ and $\mathrm{C}=\mathrm{N}$ stretching $\left(1682 \mathrm{~cm}^{-1}\right)$ were observed. These spectra indicate that the further hydroboration reaction of iminoborane species during the polymerization was almost negligible. 
Dependence of Molecular Weight of 3a on the Feed Ratio of the Monomers

The dependence of molecular weight on the feed ratio between $\mathbf{1}$ and $\mathbf{2 b}$ was studied. The results are summarized in Table II. In general, stoichiometry is quite important for the step-growth polymerization. As illustrated in Scheme 2, in the present polymerization, stepgrowth is attained by two reactions that are hydroboration of dicyano compound and dimerization of iminoborane. However, throughout the polymerization, the peak assignable to monomeric iminoborane (generally around $1850 \mathrm{~cm}^{-1}$ ) was very small or almost negligible in IR spectra. This result shows that the dimerization of iminoborane is much faster than hydroboration of dicyano compounds. Accordingly, the rate determining step might be hydroboration reaction. Therefore, feed ratio of two monomers might affect the molecular weight of the resulting polymer.

As shown in Figure 2, the molecular weight of the polymer increased when the feed ratio of two monomers

Table II. Dependence of molecular weight on the feed ratio of mesitylborane (1)/adiponitrile $(\mathbf{2 b})^{\mathrm{a}}$

\begin{tabular}{ccccc}
\hline Run & $\mathbf{1} / \mathbf{2 b}$ (ratio) & $M_{w}{ }^{\mathrm{b}}$ & $M_{n}{ }^{\mathrm{b}}$ & $M_{w} / \boldsymbol{M}_{\boldsymbol{n}}{ }^{\mathrm{b}}$ \\
\hline 1 & 0.59 & 16600 & 6300 & 2.6 \\
2 & 1.21 & 17900 & 7100 & 2.5 \\
3 & 1.60 & 22600 & 9900 & 2.3 \\
4 & 2.29 & 24600 & 12400 & 2.0 \\
5 & 2.90 & 20000 & 9600 & 2.1 \\
6 & 4.10 & 11700 & 6800 & 1.7
\end{tabular}

${ }^{a}$ Reactions were carried out by adding adiponitrile to a THF solution of mesitylborane at $0^{\circ} \mathrm{C}$ and then at room temperature. ${ }^{\mathrm{b}} \mathrm{GPC}$ (THF), polystyrene standards. approached to unity. This result supports the fact that the present polymerization proceeds in a polyaddition manner.

\section{Hydroboration Polymerization of Aliphatic Dicyano Compounds by Using Mesitylborane}

Table III summarizes the results of polymerization of 1 with various aliphatic dicyano compounds. In each case, the corresponding polymers were obtained in good yields. Monomers having longer methylene chains produced higher molecular weight polymers in comparison with those having shorter methylene chains. When 2a was employed as a dicyano monomer, the molecular weight of the obtained polymer was slightly lower than others. This might be due to some cyclizations during polymerization.

\section{Hydroboration Polymerization of Aromatic Dicyano Compounds by Using Mesitylborane}

Hydroboration polymerization between $\mathbf{1}$ and various aromatic dicyano compounds was performed. The results are listed in Table IV. In all cases, the corresponding

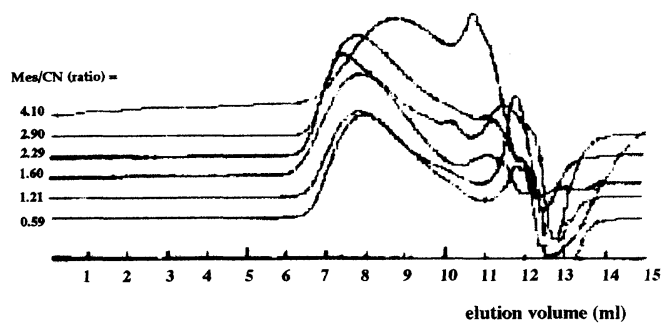

Figure 2. Dependence of molecular weight of $\mathbf{3 b}$ on the feed ratio of monomers $(\mathbf{1} / \mathbf{2 b})$

Table III. Hydroboration polymerization of aliphatic dicyano compounds (2) with mesitylborane (1) ${ }^{\mathrm{a}}$

\begin{tabular}{ccccccc}
\hline Run & Dicyano compounds & $\mathbf{1} / \mathbf{2}$ & $\boldsymbol{M}_{\boldsymbol{w}}{ }^{\mathrm{b}}$ & $\boldsymbol{M}_{n}{ }^{\mathrm{b}}$ & $\boldsymbol{M}_{\boldsymbol{w}} / \boldsymbol{M}_{\boldsymbol{n}}{ }^{\mathrm{b}}$ & Yield $/ \%^{\mathrm{c}}$ \\
\hline 1 & $\mathrm{NC}\left(\mathrm{CH}_{2}\right)_{3} \mathrm{CN}(\mathbf{2 a})$ & 2.20 & 12200 & 6900 & 1.8 & 84 \\
2 & $\mathrm{NC}\left(\mathrm{CH}_{2}\right)_{4} \mathrm{CN}(\mathbf{2 b})$ & 2.30 & 25000 & 12000 & 2.0 & 94 \\
3 & $\mathrm{NC}\left(\mathrm{CH}_{2}\right)_{5} \mathrm{CN}(\mathbf{2 c})$ & 2.29 & 26000 & 14100 & 1.8 & 95 \\
4 & $\mathrm{NC}\left(\mathrm{CH}_{2}\right)_{6} \mathrm{CN}(\mathbf{2 d})$ & 2.04 & 26500 & 16100 & 1.7 & 95 \\
5 & $\mathrm{NC}\left(\mathrm{CH}_{2}\right)_{8} \mathrm{CN}(\mathbf{2 e})$ & 2.17 & 27600 & 16400 & 1.7 & 96
\end{tabular}

${ }^{a}$ Reactions were carried out by adding dicyano compounds to a THF solution of mesitylborane at $0^{\circ} \mathrm{C}$ and then at room temperature. ${ }^{\mathrm{b}} \mathrm{GPC}$ (THF), polystyrene standards. ${ }^{\mathrm{c}}$ Isolated yields after reprecipitation into $\mathrm{MeOH} / \mathrm{H}_{2} \mathrm{O}=1 / 1(\mathrm{v} / \mathrm{v})$.

Table IV. Hydroboration polymerization of aromatic dicyano compounds (4) with mesitylborane (1) ${ }^{\mathrm{a}}$

\begin{tabular}{|c|c|c|c|c|c|c|}
\hline Run & Dicyano compounds & $1 / 4$ & $M_{w}{ }^{\mathrm{b}}$ & $M_{n}{ }^{\mathrm{b}}$ & $M_{w} / M_{n}^{\mathrm{b}}$ & Yield $/ \%^{\mathrm{c}}$ \\
\hline 1 & (4a) & 2.02 & 7400 & 4700 & 1.6 & 88 \\
\hline 1 & $\mathrm{CN} \quad(\mathbf{4 b})$ & 2.43 & 13600 & 7400 & 1.8 & 94 \\
\hline 3 & $\mathrm{CN} \quad(4 \mathrm{c})$ & 2.16 & 26000 & 13800 & 1.9 & 97 \\
\hline 4 & $-\mathrm{CN} \quad(4 \mathrm{~d})$ & 2.44 & 14300 & 8400 & 1.7 & 92 \\
\hline
\end{tabular}

${ }^{\mathrm{a}}$ Reactions were carried out by adding dicyano compounds to a THF solution of mesitylborane at $0^{\circ} \mathrm{C}$ and then at room temperature. ${ }^{\mathrm{b}} \mathrm{GPC}$ (THF), polystyrene standards. ${ }^{\mathrm{c}}$ Isolated yields after reprecipitation into $\mathrm{MeOH} / \mathrm{H}_{2} \mathrm{O}=1 / 1(\mathrm{v} / \mathrm{v})$. 


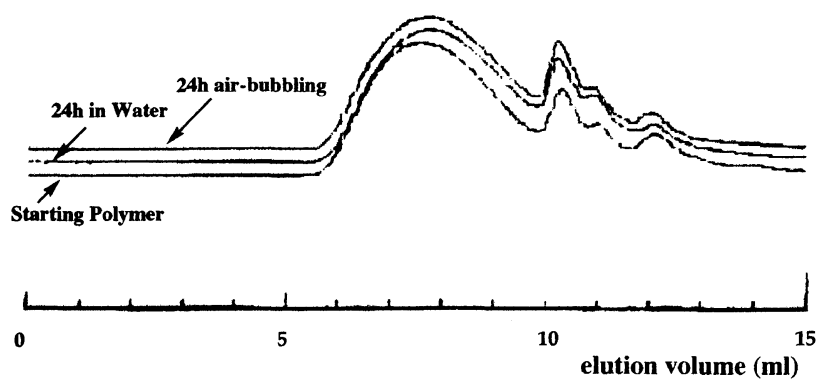

Figure 3. Stability of polymer $\mathbf{3 b}$ toward air and water.

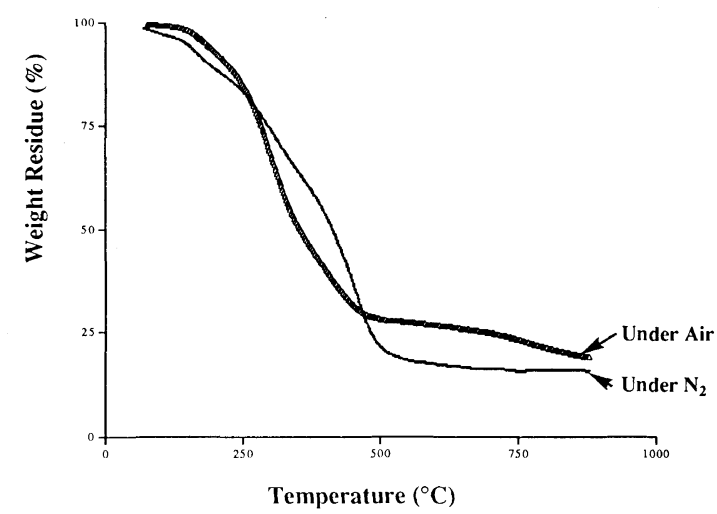

Figure 4. TGA traces of $\mathbf{3 b}$ under air and under nitrogen.

polymers were obtained in good efficiency. When $\mathbf{4 b}-\mathbf{4 d}$ were used as dicyano monomers, the molecular weights of the obtained polymers were relatively higher than that produced from $\mathbf{4 a}$. This is presumably due to improved solubility of $\mathbf{4 b} \mathbf{4} \mathbf{4 d}$ having flexible spacer in comparison with 4a. It should be noted that both aliphatic and aromatic dicyano compounds gave polymers with high molecular weights in the present polymerization. This is because further hydroboration of iminoborane species did not take place even when aliphatic dicyano compounds are used due to large steric hindrance of mesityl group. Furthermore, high viscosity of the reaction mixture was not a problem in this solution system even in the case of aromatic monomers.
Stability of the Polymer toward Air and Water

In order to study air stability of $\mathbf{3 b}$, air bubbling was performed in THF solution of polymers. The air stability was monitored by tracing the change of the molecular weight in GPC after $24 \mathrm{~h}$. Stability of $\mathbf{3 b}$ toward moisture was also studied. Water was added to a THF solution of $\mathbf{3 b}$ and the resulting mixture was stirred for $24 \mathrm{~h}$. And then the GPC curve of the resulting material was compared with that of the starting polymer. These results are shown in Figure 3. In both cases, GPC curves of the resulting polymers were almost identical to that of the starting polymer. This result supports the fact that airstable four-coordinate structure was selectively formed in the present polymerization.

\section{Thermal Stability of the Polymer}

To investigate thermal stability, thermogravimetric analysis of $\mathbf{3 b}$ was carried out under nitrogen and under air (Figure 4). In the measurement under air, the decomposition proceeded more smoothly and larger amount of residue remained in the cell. In both cases, a black solid was left after the pyrolysis. It might be taken from this result that the polymers produced by the present polymerization can be expected as a precursor for boron-containing inorganic materials.

\section{REFERENCES}

1. (a) Y. Chujo, I. Tomita, Y. Hashiguchi, H. Tanigawa, E. Ihara, and T. Saegusa, Macromolecules, 24, 345 (1991). (b) Y. Chujo, I. Tomita, and T. Saegusa, Polym. Bull., 27, 375 (1992).

2. Y. Chujo, I. Tomita, Y. Hashiguchi, and T. Saegusa, Macromolecules, 25, 33 (1992).

3. (a) Y. Chujo, I. Tomita, N. Murata, H. Mauermann, and T. Saegusa, Macromolecules, 25, 27 (1992). (b) Y. Chujo, I. Tomita, and T. Saegusa, Polym. Bull., 31, 553 (1993). (c) Y. Chujo, I. Tomita, and T. Saegusa, Polym. Bull., 31, 547 (1993). (d) Y. Chujo, I. Tomita, and T. Saegusa, Macromolecules, 27, 6714 (1994).

4. Y. Chujo, I. Tomita, and T. Saegusa, Macromolecules, 25, 3005 (1992).

5. N. Matsumi, K. Naka, and Y. Chujo, Polym. Prepr., Jpn., 46, 2473 (1997)

6. N. Matsumi and Y. Chujo, Polym. Bull., 38, 531 (1997).

7. K. Smith, A. Pelter, and Z. Jin, Angew. Chem. Int. Ed. Engl., 33, 851 (1994). 